\title{
Missing Gaps in the Estimation of the Carbon Gains Service from Light Use Efficiency Models
}

\section{A. J. Castro Martínez \\ University of Oklahoma, Oklahoma; University of Almería, Spain}

\section{J. M. Paruelo}

University of Buenos Aires, Argentina

\section{Alcaraz-Segura}

University of Granada, Spain; University of Almeria, Spain

\section{J. Cabello}

University of Almería, Spain

\section{Oyarzabal}

University of Buenos Aires, Argentina

\section{E. López-Carrique}

University of Almería, Spain

\section{CONTENTS}

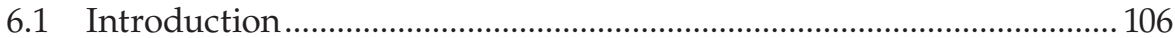

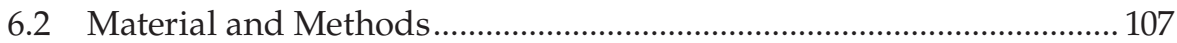

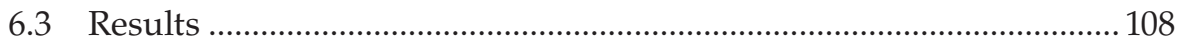

6.3.1 Estimation Methods and LUE Units ............................................ 108

6.3.2 LUE Estimates across Organizational Levels and

Land Cover Types ........................................................................ 110

6.3.3 Time Interval of LUE Estimates................................................. 112

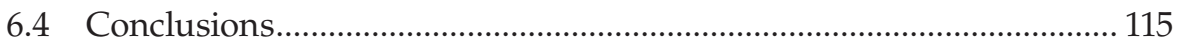




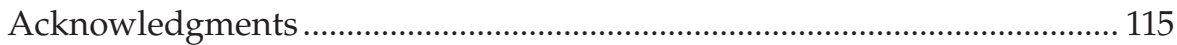

Appendix 6.1 (Articles Reviewed from 1972 to 2007).................................... 115

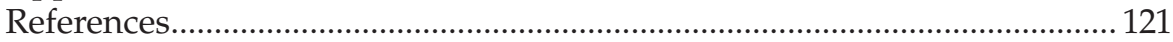

\subsection{Introduction}

The scientific community is being urged to invest more time and economic resources to improve current estimates of global and regional carbon budgets (Scurlock et al. 1999). Carbon gains are considered either as an intermediate service (Fisher et al. 2009) or as supports of provision and regulating services (MA 2005). In addition, net primary production (NPP), an estimate of ecosystem carbon gains, is often considered the most integrative descriptor of ecosystem function (McNaughton et al. 1989). NPP estimates are derived from biomass harvesting, flux tower measurements, remote sensing, and model simulation (Ruimy et al. 1995; Sala et al. 2000; Still et al. 2004). Biomass harvesting is expensive and not exempt from errors and methodological problems. These methods are limited in their spatial and temporal coverage. Given the linear relationship between the fraction of solar radiation absorbed by vegetation and spectral vegetation indices (Sellers et al. 1992), Monteith's model (Monteith 1972) offers the possibility of estimating seasonal variation in carbon gains from remote sensing data (Potter 1993). Monteith's model states that carbon gains (Equation 6.1) of vegetation cover are a function of the quantity of incoming photosynthetically active radiation (PAR), the fraction of this radiation intercepted by vegetation (fPAR), and the light use efficiency (LUE; Still et al. 2004). The flux estimated using the Monteith's model included net and gross primary production and net ecosystem exchange (NEE) (Ruimy et al. 1999; see Equations 6.2 and 6.3).

$$
\begin{aligned}
& \mathrm{NPP}=\mathrm{PAR}^{*} \mathrm{fPAR}{ }^{*} \mathrm{LUE} \\
& \mathrm{GPP}=\mathrm{PAR}^{*} \mathrm{fPAR}{ }^{*} \mathrm{LUE} \\
& \mathrm{NEE}=\mathrm{PAR}^{*} \mathrm{fPAR}{ }^{*} \mathrm{LUE}
\end{aligned}
$$

PAR can be directly measured using radiometers; fPAR can be estimated from spectral indices such as the Normalized Difference Vegetation Index (NDVI; Asrar et al. 1984) or the Enhanced Vegetation Index (EVI). The relationship of fPAR-spectral indices may vary between land cover types, but several authors have proposed different empirical relationships: (a) linear (Choudhury 1987); (b) nonlinear (Potter 1993; Sellers et al. 1994); and 
(c) a combination of both (Los et al. 2000). The LUE term has a maximum value comparable to the photosynthetic efficiency or quantum yield at leaf level under optimum conditions (Gower et al. 1999). However, low temperatures and water and nutritional stress reduce LUE value (Field et al. 1995; Gamon et al. 1995). Field et al. (1995) reported LUE differences from $0.27 \mathrm{~g} \mathrm{C/}$ MJ APAR for deserts to $0.70 \mathrm{~g} \mathrm{C} / \mathrm{MJ}$ APAR for tropical forests.

LUE was first defined at the species level and mainly for crop species (Andrade et al. 1993; Kiniry et al. 1998). The use of Monteith's model as the conceptual framework for remotely sensed estimates of aboveground net primary productivity (ANPP) (see Chapter 5) requires a definition of LUE at the ecosystem level (Ruimy et al. 1999; Sala et al. 2000; Fensholt et al. 2006). Often a single fixed value of approximately $1 \mathrm{~g} \mathrm{C} / \mathrm{MJ}$ APAR is used for a wide range of spatiotemporal situations (Maselli et al. 2009). Several authors showed that LUE varied in space (Field et al. 1995; Paruelo et al. 2004; Tong et al. 2008; Garbulsky et al. 2010) and time (Nouvellon et al. 2000; Piñeiro et al. 2006) and that the use of a single value may lead to substantial errors in regional (Hilker et al. 2008) and global (Turner et al. 2002, 2003, 2005; Tong et al. 2008) estimates of carbon gains.

Many factors affect the spatiotemporal patterns of LUE variation. Species composition, plant structure and physiology, including leaf form and RUBISCO (Ribulose-1,5-bisphosphate carboxylase oxygenase) content (Zhao et al. 2007), and environmental factors (i.e., water stress, $\mathrm{CO}_{2}$ concentration, temperature) modify LUE at the ecosystem level. Measuring LUE is not a simple task. LUE can be estimated at different levels of organization (e.g., from individuals to ecosystems), using leaf-level estimates for single individuals or eddy covariance towers to derive LUE values at the ecosystem level (Garbulsky et al. 2010).

LUE is the more uncertain parameter of the Monteith's model since it is not possible to measure it directly, and it depends on estimates of GPP/NPP/ NEE and absorbed radiation (Gower et al. 1999; Ruimy et al. 1999). This chapter reviews the reported estimates of LUE, and the effect of the time interval in LUE estimation at different organizational levels, from individuals to ecosystems. We sought to answer the following questions: (1) How was LUE estimated? (2) How did LUE differ across land cover types and levels of organization? (3) How variable are LUE estimates according to the time interval of estimation?

\subsection{Material and Methods}

We reviewed 125 articles from 1972 to 2007 containing the terms "light use efficiency" and "radiation use efficiency," but only 101 provided quantitative LUE data (Appendix 6.1). The review included 65 different journals 
primarily in the field of ecology (72\% of total studies) and remote sensing ( $22 \%$ of total studies). From the published studies, we developed a database that included the organizational level, the flux estimated, LUE estimates, and the geographical coordinates of the study site (Table 6.1). We characterized LUE values at three organizational levels: (1) "Individual" referred to local-scale studies that estimated LUE based on individuals of a single species; (2) "Single-species-dominated ecosystems" referred to when the study focused on plots with one dominant species (e.g., NEE of agroecosystem in eddy covariance flux tower with a footprint of 100 $\mathrm{m}^{2}$ ); and (3) "Multispecies-dominated ecosystems." Assuming that 50\% of the dry biomass corresponds to carbon, LUE values were transformed to the most common unit system: grams of carbon fixed per megajoules of absorbed PAR (g C/MJ APAR). To analyze the variability in LUE data, we assigned each data to one category of Archibold's (1995) classification of terrestrial land cover types. We calculated the mean, maximum, and minimum LUE values, as well as the deviation for each organizational level and land cover type. Kruskal-Wallis tests were applied to detect significant differences in LUE estimates $(n=185)$ across organizational levels and land cover types.

\subsection{Results}

\subsubsection{Estimation Methods and LUE Units}

LUE values were estimated using two main approaches. In the first approach ( $82 \%$ of total studies), LUE values were calculated at a local scale using the Monteith's equation and based on previous field estimates of a carbon flux (i.e., NPP or GPP). Here, the $20 \%$ of carbon flux estimates were derived from $\mathrm{CO}_{2}$ flux between atmosphere and vegetation observations using eddycovariance techniques (Ruimy et al. 1995; Zhao et al. 2007); fPAR data were calculated as a lineal function of satellite-derived NDVI in $44 \%$ of the total data. The remaining studies used fPAR data reported from other studies or compiled from direct measurements of the canopy. In most of the studies, PAR was calculated by radiometers.

In the second approach (18\% of total studies), LUE was estimated based on correlative models with other variables such as leaf area index (LAI) or the photochemical reflectance index (PRI; Gu et al. 2002; Filella et al. 2004; Grace et al. 2007) (see Chapter 3). Here, LUE was also derived as a ratio between the harvested biomass at the plot scale and the incoming APAR throughout an entire year or a growing season.

Most of the articles reviewed (77\% of total studies) offered quantitative estimates of LUE. From these studies, we obtained 185 LUE values that 
TABLE 6.1

Summary Sample of Light Use Efficiency Data Reviewed for 1972-2007

\begin{tabular}{|c|c|c|c|c|}
\hline $\begin{array}{l}\text { Land } \\
\text { Cover } \\
\text { Types }\end{array}$ & $\begin{array}{l}\text { Number } \\
\text { of Studies }\end{array}$ & Locations & LUE Units & $\begin{array}{l}\text { Carbon Flux Model } \\
\text { (expressed as } \\
\text { percentage of total } \\
\text { studies within biome) }\end{array}$ \\
\hline PHM & 1 & Alaska & $\mathrm{g} \mathrm{C} / \mathrm{MJ}$ APAR & $(100 \%)$ Other* \\
\hline $\mathrm{CF}$ & 49 & $\begin{array}{l}\text { Durham, Canada, } \\
\text { Wisconsin, } \\
\text { Sweden }\end{array}$ & $\begin{array}{l}\mathrm{g} \mathrm{C} / \mathrm{MJ} \text { APAR Mol } \\
\mathrm{C} / \mathrm{mol} \text { photons } \\
\mathrm{Moles}^{\mathrm{CO}_{2} /} \\
\text { mol PAR }\end{array}$ & $\begin{array}{l}(8 \%) \mathrm{GPP}=\mathrm{APAR}^{*} \mathrm{LUE} \\
(16 \%) \mathrm{NEE}=\mathrm{APAR}^{*} \mathrm{LUE} \\
(32 \%) \mathrm{NPP}=\mathrm{APAR}^{*} \mathrm{LUE} \\
(44 \%) \text { Other }\end{array}$ \\
\hline TW & 12 & $\begin{array}{l}\text { Canada, Europe, } \\
\text { EEUU }\end{array}$ & $\begin{array}{l}\mathrm{g} \mathrm{C} / \mathrm{MJ} \mathrm{APAR} \\
\mathrm{Mol} \mathrm{C/mol} \\
\text { photons } \\
\text { Moles } \mathrm{CO}_{2} / \\
\text { mol PAR }\end{array}$ & $\begin{array}{l}(8 \%) \text { ANPP }=\text { APAR } * \text { LUE } \\
(29 \%) \text { NPP }=\text { APAR } * \text { LUE } \\
(29 \%) \text { Other }\end{array}$ \\
\hline $\mathrm{Cr}$ & 38 & $\begin{array}{l}\text { Ireland, EEUU, } \\
\text { China, Italy, } \\
\text { Australia, United } \\
\text { Kingdom, South } \\
\text { Africa, India }\end{array}$ & $\begin{array}{l}\mathrm{g} \mathrm{C} / \mathrm{MJ} \\
\mathrm{Kg}\left(\mathrm{CO}_{2} / \mathrm{ha} \cdot \mathrm{h}\right) / \\
\left(\mathrm{J} / \mathrm{m}^{2} \cdot \mathrm{sg}\right)\end{array}$ & $\begin{array}{l}(30 \%) \text { NPP }=\text { APAR } * U E \\
(70 \%) \text { Other } *\end{array}$ \\
\hline TFE & 65 & $\begin{array}{c}\text { Europe, EEUU, } \\
\text { Japan, China, } \\
\text { New Zealand }\end{array}$ & $\begin{array}{l}\mathrm{g} \mathrm{C} / \mathrm{MJ} \text { APAR } \\
\mathrm{Mol} \mathrm{CO}_{2} / \\
\text { mol APAR } \\
\mathrm{mmol} \mathrm{CO}_{2} / \\
\text { mmol photons }\end{array}$ & $\begin{array}{l}(8 \%) \mathrm{GPP}=\mathrm{APAR}^{*} \mathrm{LUE} \\
(32 \%) \mathrm{NEE}=\mathrm{APAR} * \text { LUE } \\
(27 \%) \mathrm{NPP}=\mathrm{APAR}{ }^{*} \mathrm{LUE} \\
(33 \%) \text { Other }\end{array}$ \\
\hline $\mathrm{ME}$ & 12 & $\begin{array}{l}\text { Spain, Italy, India, } \\
\text { EEUU }\end{array}$ & $\begin{array}{l}\mathrm{g} \mathrm{C} / \mathrm{MJ} \text { APAR } \\
\mathrm{Mol} \mathrm{C} / \mathrm{mol} \text { APAR }\end{array}$ & $\begin{array}{l}(20 \%) \mathrm{NEE}=\mathrm{APAR}^{*} \mathrm{LUE} \\
(70 \%) \mathrm{NPP}=\mathrm{APAR}{ }^{*} \mathrm{LUE} \\
(10 \%) \text { Other }\end{array}$ \\
\hline TG & 16 & $\begin{array}{l}\text { Canada, EEUU, } \\
\text { Argentina }\end{array}$ & $\begin{array}{l}\mathrm{g} C / \mathrm{MJ} \text { APAR } \\
\mathrm{g} \mathrm{DM} / \mathrm{MJ}\end{array}$ & $\begin{array}{l}(13 \%) \mathrm{NEE}=\mathrm{APAR}^{*} \mathrm{LUE} \\
(40 \%) \mathrm{NPP}=\mathrm{APAR}^{*} \mathrm{LUE} \\
(47 \%) \text { Other }\end{array}$ \\
\hline $\mathrm{TpF}$ & 4 & $\begin{array}{l}\text { Panama, } \\
\text { Colombia, EEUU }\end{array}$ & $\begin{array}{l}\mathrm{g} \mathrm{C} / \mathrm{MJ} \text { APAR } \\
\mathrm{Kg}\left(\mathrm{CO}_{2} / \mathrm{ha} \cdot \mathrm{h}\right) / \\
\left(\mathrm{J} / \mathrm{m}^{2} \cdot \mathrm{sg}\right)\end{array}$ & $\begin{array}{l}(67 \%) \mathrm{GPP}=\mathrm{APAR}^{*} \mathrm{LUE} \\
(33 \%) \mathrm{NEE}=\mathrm{APAR}^{*} \mathrm{LUE}\end{array}$ \\
\hline TpS & 9 & Senegal, Argentina & $\begin{array}{l}\mathrm{g} \mathrm{C} / \mathrm{MJ} \text { APAR } \\
\mathrm{Mol} \mathrm{C/mol} \mathrm{APAR}\end{array}$ & $(100 \%)$ Other* \\
\hline $\mathrm{AR}$ & 8 & $\begin{array}{l}\text { Sahara, Southern } \\
\text { Australia, Mali, } \\
\text { Mexico }\end{array}$ & $\begin{array}{l}\text { g C/MJ APAR } \\
\text { gr DM/MJ }\end{array}$ & $\begin{array}{l}(17 \%) \mathrm{GPP}=\mathrm{APAR}^{*} \mathrm{LUE} \\
(50 \%) \mathrm{NPP}=\mathrm{APAR}{ }^{*} \mathrm{LUE} \\
(33 \%) \text { Other }\end{array}$ \\
\hline
\end{tabular}

Note: Other* expresses (a) when the study did not specify the carbon flux model for LUE estimation, (b) modifications of Monteith's model such as NASA-CASA model (i.e., CarnegieAmes-Stanford Approach) simulates net primary productivity and the soil heterotrophic respiration at regional to global scales or the TURC model for the estimation of the continental gross primary productivity and net primary productivity, or derived models by Montetih's approach based on the inclusion of other physiological parameters, and (c) a constant LUE value. Archibold's land cover type classification: $\mathrm{PHM}=$ polar and high mountain tundra, $\mathrm{CF}=$ coniferous forests, $\mathrm{TW}=$ terrestrial wetlands, $\mathrm{Cr}=$ crops, $\mathrm{TFE}=$ temperate forest ecosystems, $\mathrm{ME}=$ Mediterranean ecosystems, $\mathrm{TG}=$ temperate grasslands, $\mathrm{TpF}=$ tropical forests, $\mathrm{TpS}=$ tropical savannas, and $\mathrm{AR}=$ arid regions. 
were originally expressed in four different units, including g C/MJ APAR $(65 \%)$, mol $\mathrm{CO}_{2} / \mathrm{mol}$ APAR $(14 \%)$, g of dry matter/MJ APAR (9\%), and mol $\mathrm{C} / \mathrm{mol}$ absorbed photons per minute $(3 \%)$. After converting to $\mathrm{g} \mathrm{C} / \mathrm{MJ}$ APAR, the average LUE value was $0.99 \mathrm{~g} \mathrm{C} / \mathrm{MJ}$ APAR (SD = 1.09), with an absolute maximum of $8.2 \mathrm{~g} \mathrm{C} / \mathrm{MJ}$ APAR and an absolute minimum of $0.05 \mathrm{~g} \mathrm{C} / \mathrm{MJ}$ APAR.

\subsubsection{LUE Estimates across Organizational Levels and Land Cover Types}

The number of studies varied among organizational levels and land cover types (Figure 6.1). The multispecies-dominated ecosystems level was the most commonly studied (62\%) followed by single-species-dominated ecosystems (19\%) and individuals (19\%). Temperate forests, coniferous forests, and croplands were the most highly represented land cover types in the literature reviewed, and the least represented were polar and high mountain tundra, tropical forests, and arid regions (Figure 6.1). Croplands and temperate forest ecosystems were the unique land cover types studied at all levels of organization.

We found that the average LUE values at the individual level (1.7 $\mathrm{g} \mathrm{C} / \mathrm{MJ}$ APAR; SD = 1.6) were significantly higher than at the multispecies-dominated (0.8 g C/MJ APAR; $\mathrm{SD}=0.9$ ) and single-species-dominated

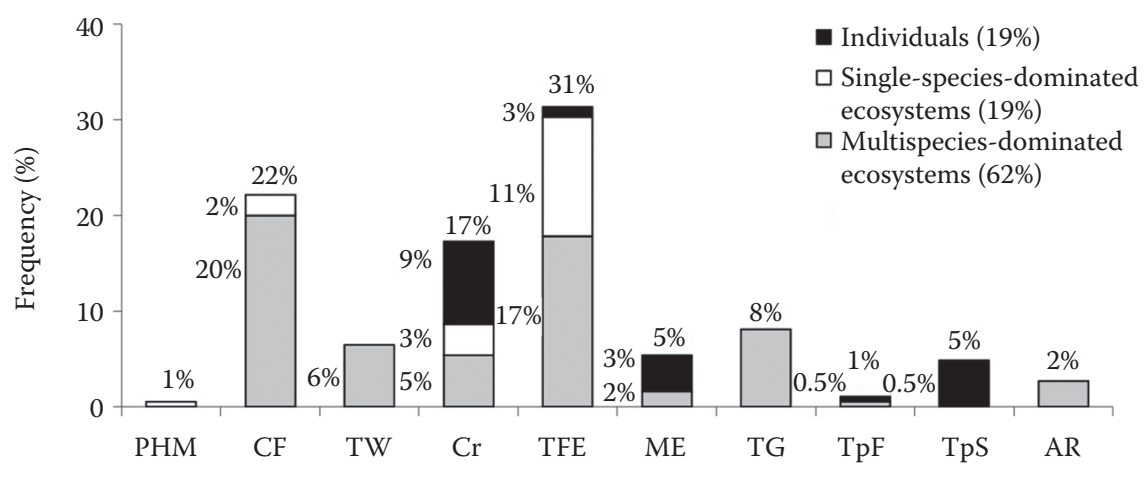

Land cover types

FIGURE 6.1

Frequency of articles for land cover types at individual, single-species-dominated ecosystems, and multispecies-dominated ecosystems levels. Total LUE values = 185. Archibold's land cover type classification: $\mathrm{PHM}=$ polar and high mountain tundra, $\mathrm{CF}=$ coniferous forests, $\mathrm{TW}=$ terrestrial wetlands, $\mathrm{Cr}=$ crops, $\mathrm{TFE}=$ temperate forest ecosystems, $\mathrm{ME}=$ Mediterranean ecosystems, $\mathrm{TG}=$ temperate grasslands, $\mathrm{TpF}=$ tropical forests, $\mathrm{TpS}=$ tropical savannas, and $\mathrm{AR}=$ arid regions. 


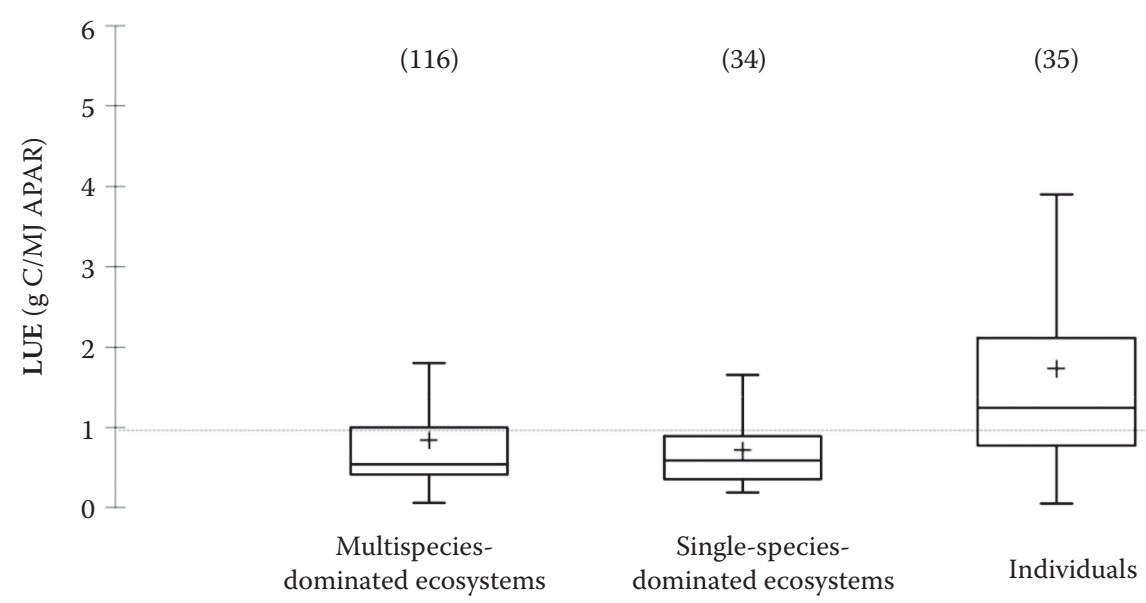

\section{FIGURE 6.2}

Box plot of light use efficiency (LUE) values at multispecies-dominated ecosystems, singlespecies-dominated ecosystems, and individual levels. The graphic explains the minimum, first quartile $(25 \%)$, median, mean, and third quartile $(75 \%)$ of LUE values. The mean is displayed with $\mathrm{a}+$, and a black line corresponds to the median. The maximum LUE value at the individual level was $8.2 \mathrm{~g} \mathrm{C} / \mathrm{MJ}$ APAR; at the single-species-dominated ecosystems level, it was $2 \mathrm{~g} \mathrm{C} / \mathrm{MJ}$ APAR; and at multispecies-dominated ecosystem level, it was $5.7 \mathrm{~g} \mathrm{C} / \mathrm{MJ}$ APAR. The horizontal dotted line represents the total average of LUE values. The total LUE values per box plot appear in brackets.

(0.7 g C/MJ APAR; SD = 0.4) ecosystems levels (Figure 6.2). Average LUE values by land cover type exhibited significant differences (Figure 6.3). The average LUE values varied between $2.20 \mathrm{~g} \mathrm{C} / \mathrm{MJ}$ APAR $(\mathrm{SD}=1.67)$ in croplands and $0.55 \mathrm{~g} \mathrm{C} / \mathrm{MJ}$ APAR $(\mathrm{SD}=0.23)$ in terrestrial wetlands. The maximum LUE was found in crops (8.20 g C/MJ APAR) and temperate grasslands (5.20 g C/MJ APAR), whereas the minimum LUE value was observed in tropical savannas (0.05 $\mathrm{g} \mathrm{C} / \mathrm{MJ} \mathrm{APAR})$ and temperate grasslands $(0.06 \mathrm{~g} \mathrm{C} / \mathrm{MJ}$ APAR) (Figure 6.3).

At the individual level, significant differences in LUE were observed between tropical savannas, tropical forests, and crops (Figure 6.4). At the single-species-dominated ecosystems level, coniferous forests and crops were significantly different in LUE values (Figure 6.4). At the multispeciesdominated ecosystems level, crops were significantly different from coniferous forests, terrestrial wetlands, tropical forests, and Mediterranean ecosystems. Temperate grasslands and tropical forest ecosystems were significantly different from coniferous forest, terrestrial wetlands, and temperate forest ecosystems (Figure 6.4).

Although LUE estimates were not available in the literature for all organizational levels, we observed significant differences within land 


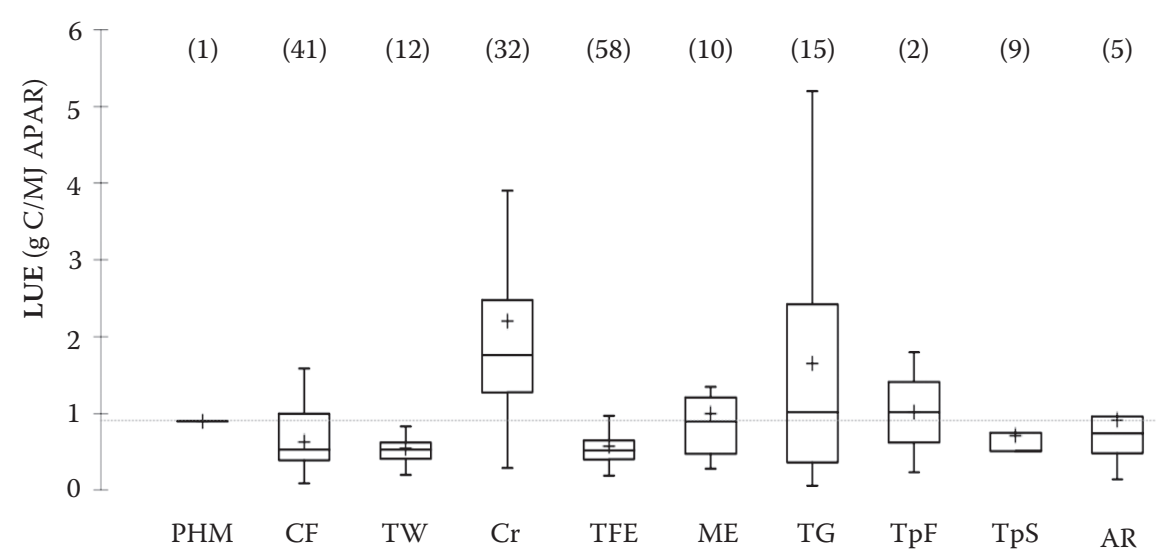

FIGURE 6.3

Box plot of light use efficiency (LUE) values by land cover types. The graphic explains the minimum, first quartile (25\%), median, mean, and third quartile $(75 \%)$ of LUE values. The mean is displayed with $\mathrm{a}+$, and a black line corresponds to the median. Total LUE values = 185. Archibold's land cover type classification: $\mathrm{PHM}=$ polar and high mountain tundra, $\mathrm{CF}=$ coniferous forests, TW $=$ terrestrial wetlands, $\mathrm{Cr}=$ crops, $\mathrm{TFE}=$ temperate forest ecosystems, $\mathrm{ME}=$ Mediterranean ecosystems, $\mathrm{TG}=$ temperate grasslands, $\mathrm{TpF}=$ tropical forests, $\mathrm{TpS}=$ tropical savannas, and $\mathrm{AR}=$ arid regions.

cover types. Coniferous forests showed significant differences between single-species-dominated and multispecies-dominated ecosystems levels. In temperate forest ecosystems, we observed significant differences between the individual and single-species-dominated ecosystems and multispeciesdominated ecosystems levels (Figure 6.4). In Mediterranean ecosystems, differences were observed between the individual and multispecies-dominated ecosystems levels. Crops, represented at all levels of organization, were the only land cover type showing no significant differences. Tropical forest ecosystems with values for individual and multispecies-dominated ecosystems levels did not exhibit significant differences (Figure 6.4).

\subsubsection{Time Interval of LUE Estimates}

LUE values significantly differed according to the time interval of the estimation (i.e., sampled within a day, season, or year). Annual and seasonal estimates were obtained for all organizational levels. Daily LUE estimates were only found in the literature at the multispecies-dominated ecosystems level. Significant differences between measurement time intervals were detected at the single-species-dominated ecosystems level between annual and seasonal LUE estimates. Kruskal-Wallis tests did not reveal significant differences in annual and seasonal estimates at the individual level and for annual, seasonal, and daily estimates at 


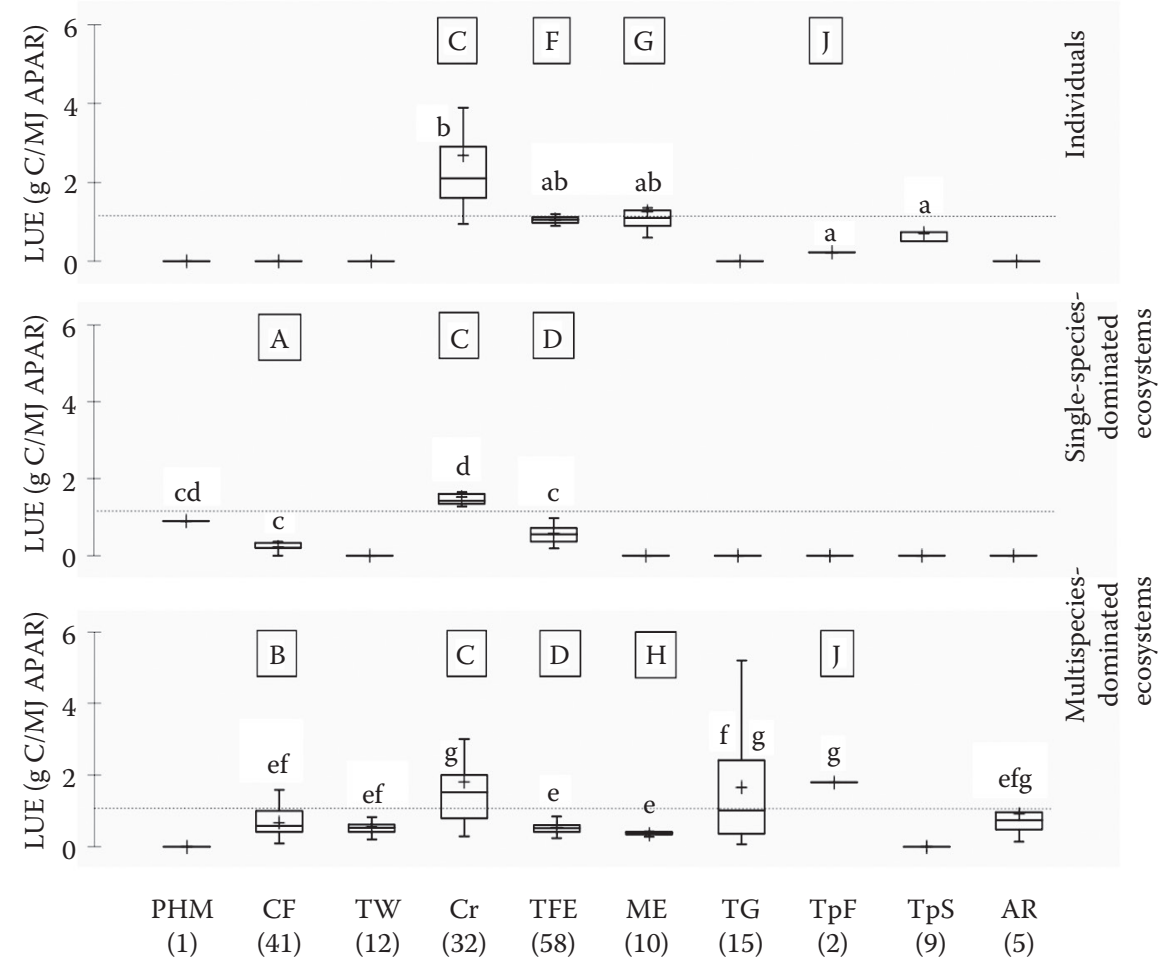

FIGURE 6.4

Box plot of light use efficiency (LUE) values comparing values between organizational levels and land cover types. The graphic explains the minimum, maximum, first quartile (25\%), median, mean, and third quartile (75\%) of LUE values. The mean is displayed with a + , and a black line corresponds to the median. Letters indicate significantly different groups (KruskalWallis test, $\mathrm{p}<0.05)$. Lowercase letters indicate significantly different groups within each organizational level and between land cover types. Uppercase letters indicate significantly different groups between organizational levels and per each land cover type. Total LUE values $=185$. Archibold's land cover type classification: $\mathrm{PHM}=$ polar and high mountain tundra, $\mathrm{CF}$ $=$ coniferous forests, $\mathrm{TW}=$ terrestrial wetlands, $\mathrm{Cr}=$ crops, $\mathrm{TFE}=$ temperate forest ecosystems, $\mathrm{ME}=$ Mediterranean ecosystems, $\mathrm{TG}=$ temperate grasslands, $\mathrm{TpF}=$ tropical forests, $\mathrm{TpS}=$ tropical savannas; and $\mathrm{AR}=$ arid regions.

the multispecies-dominated ecosystems level. However, we observed significant differences between annual and seasonal estimates at the single-species-dominated ecosystems level. A comparison between the time interval of the estimation and the organizational levels (Figure 6.5) revealed significant differences between LUE obtained in annual and seasonal observations. Annual and seasonal estimates were not significantly different at the multispecies-dominated and single-species-dominated ecosystems levels, but we did detect significant differences with the results obtained at the individual level. 

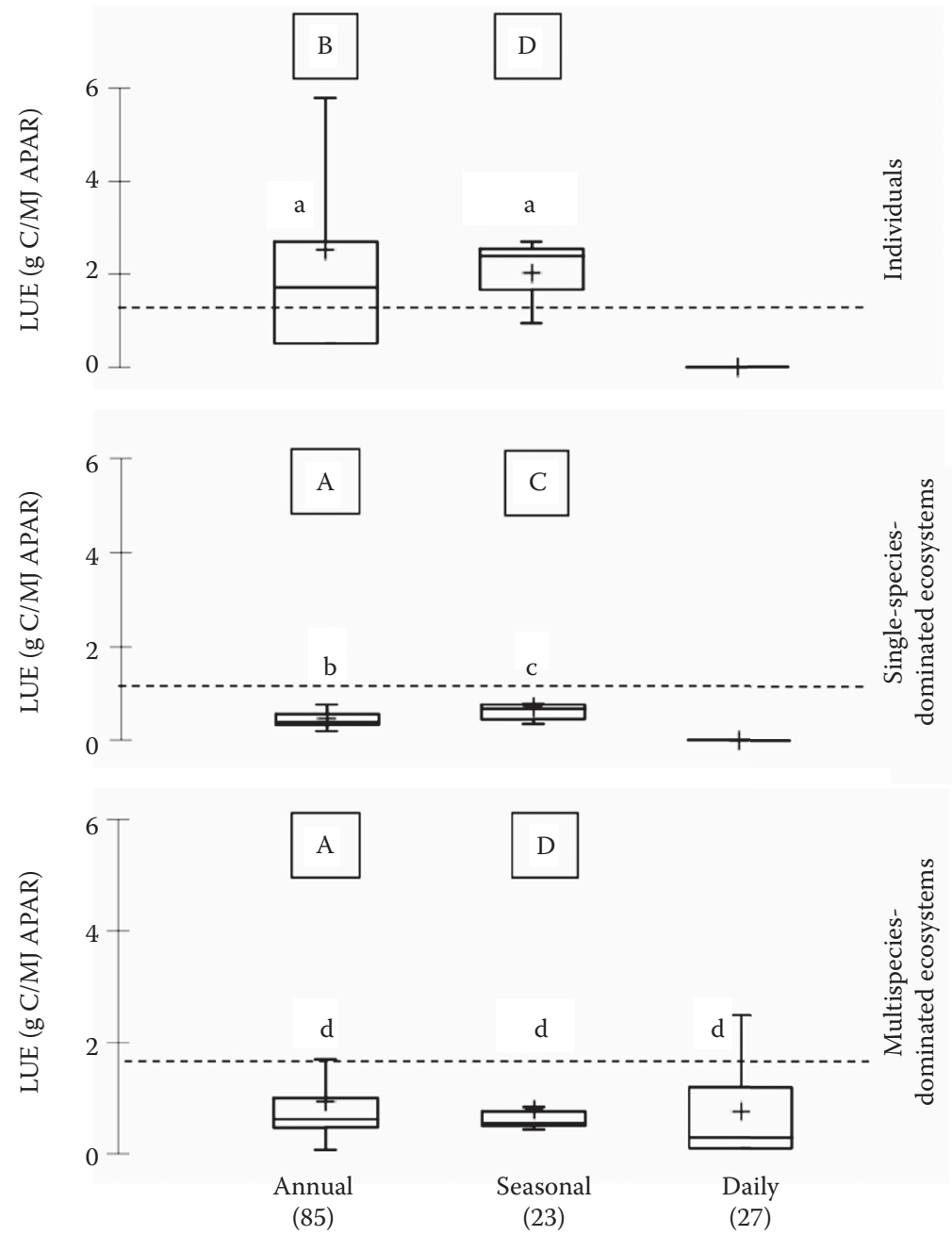

\section{FIGURE 6.5}

Box plot of temporal variation of average light use efficiency (LUE) values in each organizational level and the estimate periods. The graphic explains the minimum, maximum, first quartile (25\%), median, mean, and third quartile (75\%) of LUE values. The mean is displayed with a + , and a black line corresponds to the median. Different letters indicate significant differences (Kruskal-Wallis test, $\mathrm{p}<0.05$ ). Lower case letters indicate significantly different groups between time interval of estimation and within each organizational level. Capital letters indicate significantly different groups between organizational levels and the time interval of estimation. Total LUE values $=185$. Archibold's land cover type classification: $\mathrm{PHM}=$ polar and high mountain tundra, $\mathrm{CF}=$ coniferous forests, $\mathrm{TW}=$ terrestrial wetlands, $\mathrm{Cr}=$ crops, $\mathrm{TFE}=$ temperate forest ecosystems, $\mathrm{ME}=$ Mediterranean ecosystems, $\mathrm{TG}=$ temperate grasslands, $\mathrm{TpF}=$ tropical forests, $\mathrm{TpS}=$ tropical savannas, and $\mathrm{AR}=$ arid regions. 


\subsection{Conclusions}

Monteith's model, based on LUE and remotely sensed estimates of fPAR, constitutes the most widely used approach for mapping the terrestrial carbon cycle (Jenkins et al. 2007; Pereira et al. 2007), though it is not free of uncertainties. The inherent spatiotemporal variability found among different methodologies may explain the variability of LUE estimates found in this study. The time interval of the estimates and the level of organization are two clear sources of such variation. In such a way, annual estimates of NPP at regional scale should not be used for LUE estimation at individual level and derive for short-term (e.g., days) measurements. The variability of LUE estimates related to environmental and physiological factors (such as leaf form, ribulose diphosphate carboxylase content, temperature, and/or moisture) (Ito and Oikawa 2007; Tong et al. 2008) can result in large errors if these values are extrapolated to global or regional scales (Nouvellon et al 2000; Piñeiro et al. 2006). Our results indicated that high temporal variation in LUE estimates at the individual and multispecies-dominated ecosystems levels across land cover types (see also Grace et al. 2007; Cook et al. 2008; Hilker et al. 2008) do not account for regional and global NPP estimates, which typically apply a constant LUE value (Drolet et al. 2008; Maselli et al. 2009).

\section{Acknowledgments}

The authors gratefully acknowledge the staff of the Andalusian Government's Department of the Environment for providing the facilities required to obtain the necessary assistance. They also thank Gervasio Piñeiro, Dolores Arocena, Carlos Di Bella, Piedad Cristiano, and two anonymous reviewers for their useful comments. Financial support was provided by the ERDF (FEDER), Andalusian Regional Government (Junta de Andalucía GLOCHARID \& SEGALERT Projects, P09-RNM-5048), and the Ministry of Science and Innovation (Project CGL2010-22314). Support for A. J. C. was also provided by the Centro Andaluz para la Evaluación y Seguimiento del Cambio Global (CAESCG) and the Oklahoma Biological Survey (OBS) at the University of Oklahoma.

\section{Appendix 6.1 (Articles Reviewed from 1972 to 2007)}

Aalto, T., P. Ciais, A. Chevillard, and C. Moulin. 2004. Optimal determination of the parameters controlling biospheric $\mathrm{CO}_{2}$ fluxes over Europe using eddy covariance fluxes and satellite NDVI measurements. Tellus B 56:93-104. 
Ahl, D. E., S. T. Gower, D. S. Mackay, S. N. Burrows, J. M. Norman, and G. R. Diak. 2004. Heterogeneity of light use efficiency in a northern Wisconsin forest: Implications for modeling net primary production with remote sensing. Remote Sensing of Environment 93:168-178.

Ahl, D. E., S. T. Gower, D. S. Mackay, S. N. Burrows, J. M. Norman, and G. R. Diak. 2005. The effects of aggregated land cover data on estimating NPP in northern Wisconsin. Remote Sensing of Environment 97:1-14.

Anderson, M. C., W. P. Kustas, and J. M. Norman. 2007. Upscaling flux observations from local to continental scales using thermal remote sensing. Agronomy Journal 99:240-254.

Asner, G. P., K. M. Carlson, and R. E. Martin. 2005. Substrate age and precipitation effects on Hawaiian forest canopies from spaceborne imaging spectroscopy. Remote Sensing of Environment 98:457-467.

Asrar, G., M. Fuchs, E. T. Kanemasu, and J. L. Hatfield. 1984. Estimating absorbed photosynthetic radiation and leaf-area index from spectral reflectance in wheat. Agronomy Journal 76:300-306.

Baldocchi, D. D. 2003. Assessing the eddy covariance technique for evaluating carbon dioxide exchange rates of ecosystems: Past, present and future. Global Change Biology 9:479-492.

Black, T. A., D. Gaumont-Guay, R. S. Jassal, et al. 2005. Measurement of carbon dioxide exchange between the boreal forest and the atmosphere. In Carbon balance of forest biomes, eds. H. Griffiths and P. G. Jarvis, 151-185. Oxfordshire, UK: BIOS Scientific Publishers.

Boschetti, L., P. A. Brivio, H. D. Eva, J. Gallego, A. Baraldi, and J. M. Gregoire. 2006. A sampling method for the retrospective validation of global burned area products. IEEE-Transactions on Geoscience and Remote Sensing 44:1765-1773.

Bradford, J. B., J. A. Hickec, and W. K. Lauenroth. The relative importance of light-use efficiency modifications from environmental conditions and cultivation for estimation of large-scale net primary productivity. Remote Sensing of Environment 96:246-255.

Cannell, M. G. R., R. Milne, L. J. Sheppard, and M. H. Unsworth. 1987. Radiation interception and productivity of willow. Journal of Applied Ecology 24:261-278.

Christensen, S., and J. Goudriaan. 1993. Deriving light interception and biomass from spectral reflectance ratio. Remote Sensing of the Environment 43:87-95.

D'Antuono, L. F., and F. Rossini. 2006. Yield potential and ecophysiological traits of the Altamurano linseed (Linum usitatissimum L.), a landrace of southern Italy. Genetic Resources and Crop Evolution 53:65-75.

Drolet, G. G., K. F. Huemmrich, F. G. Hall, et al. 2005. A MODIS-derived photochemical reflectance index to detect inter-annual variations in the photosynthetic light-use efficiency of a boreal deciduous forest. Remote Sensing of Environment 98:212-224.

Dungan, R. J., and D. Whitehead. 2006. Modelling environmental limits to light use efficiency for a canopy of two broad-leaved tree species with contrasting leaf habit. New Zealand Journal of Ecology 30:251-259.

Fang, S., X. Xizeng, X. Xiang, and L. Zhengcai. 2005. Poplar in wetland agroforestry: A case study of ecological benefits, site productivity, and economics. Wetlands Ecology and Management 13:93-104.

Fensholt, R., I. Sandholt, and M. S. Rasmussen. 2004. Evaluation of MODIS LAI, fAPAR and the relation between FAPAR and NDVI in a semi-arid environment using in situ measurements. Remote Sensing of Environment 91:490-507. 
Fensholt, R., I. Sandholt, M. S. Rasmussen, S. Stisen, and A. Diouf. 2006. Evaluation of satellite based primary production modeling in the semi-arid Sahel. Remote Sensing of Environment 105:173-188.

Fernández, M. E., J. E. Gyenge, and T. M. Schlichter. 2006. Growth of the grass Festuca pallescens in silvopastoral systems in a semi-arid environment, Part 1: Positive balance between competition and facilitation. Agroforestry Systems 66:259-269.

Field, C. B., J. T. Randerson, and C. M. Malmstrom. 1995. Global net primary production: Combining ecology and remote sensing. Remote Sensing of Environment 51:74-88.

Fleisher, D. H., D. J. Timlin, and V. R. Reddy. 2006. Temperature influence on potato leaf and branch distribution and on canopy photosynthetic rate. Agronomy Journal 98:1442-1452.

Fuentes, D., J. A. Gamon, Y. Cheng, et al. 2006. Mapping carbon and water flux in a chaparral ecosystem using vegetation indices derived from AVIRIS. Remote Sensing of Environment 103:312-323.

Gamon, J. A., K. Kitajima, S. S. Mulkey, L. Serrano, and S. J. Wright. 2005. Diverse optical and photosynthetic properties in a neotropical dry forest during the dry season: Implications for remote estimation of photosynthesis. Biotropica 37:547-560.

Gebremichael, M., and A. P. Barros. 2006. Evaluation of MODIS gross primary productivity (GPP) in tropical monsoon regions. Remote Sensing of Environment 100:150-166.

Goetz, S. J., and S. D. Prince. 1999. Modelling terrestrial carbon exchange and storage: Evidence and implications of functional convergence in light-use efficiency. Advances in Ecological Research 28:57-92.

Goetz, S. J., S. D. Prince, S. N. Goward, M. M. Thawle, J. Small, and A. Johnston. 1999. Mapping net primary production and related biophysical variables with remote sensing: Application to the Boreas region. Journal of Geophysical ResearchAtmospheres 104:27719-27734.

Goulden, M. L., J. W. Munge, S. M. Fan, B. C. Daube, and S. C. Wofsy. 1996. Exchange of carbon dioxide by a deciduous forest: Response to interanual climate variability. Science 271:1576-1578.

Goward, S. N., and D. G. Dye. 1987. Evaluating North American net primary productivity with satellite observations. Advances in Space Research 7:165-174.

Goward, S. N., and K. F. Huemmrich. 1992. Vegetation canopy PAR absorbance and the normalized difference vegetation index: An assessment using the SAIL model. Remote Sensing of the Environment 39:119-140.

Guo, J., and C. M. Trotter. 2004. Estimating photosynthetic light-use efficiency using the photochemical reflectance index: Variations among species. Functional Plant Biology 31:255-265.

Hill, M., A. A. Held, R. Leuning, et al. 2006. MODIS spectral signals at a flux tower site: Relationships with high-resolution data, and $\mathrm{CO}_{2}$ flux and light use efficiency measurements. Remote Sensing of Environment 103:351-368.

Inoue, Y., and J. Peñuelas. 2006. Relationships between light use efficiency and photochemical reflectance index in soybean leaves as affected by soil water content. International Journal of Remote Sensing 27:5109-5114.

Ito, A., and T. Oikawa. 2004. Global mapping of terrestrial primary productivity and light-use efficiency with a process-based model. In Global environmental change in the ocean and on land, eds. M. Shiyomi, H. Kawahata, H. Koizumi, A. Tsuda, and Y. Awaya, 343-358. Tokyo: Terrapub. 
Kato, T., Y. Tang, S. Gu, et al. 2006. Temperature and biomass influences on interannual changes in $\mathrm{CO}_{2}$ exchange in an alpine meadow on the Qinghai-Tibetan Plateau. Global Change Biology 12:1285-1298.

Kinirya, J. R., C. E. Simpsonb, A. M. Schubertc, and J. D. Reed. Peanut leaf area index, light interception, radiation use efficiency, and harvest index at three sites in Texas. Field Crops Research 91:297-306.

Krishnan, P., T. A. Black, N. J. Grant, et al. 2006. Carbon dioxide and water vapour exchange in a boreal aspen forest during and following severe drought. Agricultural and Forest Meteorology 139:208-223.

Lagergren, F. 2005. Net primary production and light use efficiency in a mixed coniferous forest in Sweden. Plant, Cell \& Environment 28:412-423.

Leuning, R., H. A. Cleugh, S. J. Zegelin, and D. Hughes. 2005. Carbon and water fluxes over a temperate Eucalyptus forest and a tropical wet/dry savanna in Australia: Measurements and comparison with MODIS remote sensing estimates. Agricultural and Forest Meteorology 129:151-173.

Li, S. G., J. Asanuma, W. Eugster, et al. 2005. Net ecosystem carbon dioxide exchange over grazed steppe in central Mongolia. Global Change Biology 11:1941-1955.

Li, S. G., W. Eugster, J. Asanuma, et al. 2006. Energy partitioning and its biophysical controls above a grazing steppe in central Mongolia. Agricultural and Forest Meteorology 137:89-106.

Monteith, J. L. 1972. Solar-radiation and productivity in tropical ecosystems. Journal of Applied Ecology 9:747-766.

Monteith, J. L. 1977. Climate and the efficiency of crop production in Britain. Philosophical Transactions of the Royal Society of London B 281:277-297.

Monteith, J. L. 1994. Validity of the correlation between intercepted radiation and biomass. Agricultural and Forest Meteorology 68:213-220.

Myneni, R. B., S. Hoffman, Y. Knyazikhin, et al. 2002. Global products of vegetation leaf area and fraction absorbed PAR from year one of MODIS data. Remote Sensing of Environment 83:214-231.

Myneni, R. B., R. R. Nemani, and S. W. Running. 1997. Estimation of global leaf área index and absorbed PAR using radiative transfer models. IEEE Transactions on Geoscience and Remote Sensing 35:1380-1393.

Myneni, R. B., and D. L. Williams. 1994. On the relationship between fAPAR and NDVI. Remote Sensing of Environment 49:200-11.

Nakaji, T., H. Oguma, and Y. Fujinuma. 2006. Seasonal changes in the relationship between photochemical reflectance index and photosynthetic light use efficiency of Japanese larch needles. International Journal of Remote Sensing 27:493-509.

Nakaji, T., T. Takeda, Y. Fujinuma, and H. Oguma. 2005. Effect of autumn senescence on the relationship between the PRI and LUE of young Japanese larch trees. Phyton 45:535-542.

Nemani, R. R., and S. W. Running. 1989. Estimation of regional surface-resistance to evapotranspiration from NDVI and thermal-IR AVHRR data. Journal of Applied Meteorology 28:276-284.

Nichol, C. J., K. F. Huemmrich, T. A. Black, et al. 2002. Sensing of photosynthetic-lightuse efficiency of boreal forest. Agricultural and Forest Meteorology 101:131-142.

Nichol, C. J., J. Lloyd, O. Shibistova, et al. 2002. Remote sensing of photosyntheticlight-use efficiency of a Siberian boreal forest. Tellus B 54:677-687. 
Niinemets, U., A. Cescatti, and R. Christian. 2004. Constraints on light interception efficiency due to shoot architecture in broad-leaved Nothofagus species. Tree Physiology 24:617-630.

Niinemets, U., and L. Sack. 2006. Structural determinants of leaf light-harvesting capacity and photosynthetic potentials. Progress in Botany 67:385-419.

Norby, R. J., J. Ledford, C. D. Reilly, et al. 2004. Fine-root production dominates response of a deciduous forest to atmospheric $\mathrm{CO}_{2}$ enrichment. Proceedings of the National Academy of Sciences of the United States of America 101:9689-9693.

Nouvellon, Y., D. Lo Seen, S. Rambal, et al. 2000. Time course of radiation use efficiency in a shortgrass ecosystem: Consequences for remotely sensed estimation of primary production. Remote Sensing of Environment 71:43-55.

Paruelo, J. M., H. E. Epstein, W. K. Lauenroth, and I. C. Burke. 1997. ANPP estimates from NDVI for the central grassland region of the US. Ecology 78:953-958.

Paruelo, J. M., M. Oesterheld, C. M. Di Bella, et al. 2000. Estimation of primary production of subhumid rangelands from remote sensing data. Applied Vegetation Science 3:189-195.

Patel, N. R. 2006. Investigating relations between satellite derived land surface parameters and meteorological variables Geocarto International 21:47-53.

Pereira, J. S., J. A. Mateus, L. M. Aires, et al. 2007. Net ecosystem carbon exchange in three contrasting Mediterranean ecosystems: The effect of drought. Biogeosciences 4:791-802.

Piñéiro, G., M. Oesterheld, and J. M. Paruelo. 2006. Seasonal variation in aboveground production and radiation use efficiency of temperate rangelands estimated through remote sensing. Ecosystems 9:357-373.

Pitman, J. I. 2000. Absorption of photosynthetically active radiation, radiation use efficiency and spectral reflectance of bracken [Pteridium aquilinum (L.) Kuhnl] canopies. Annals of Botany 85:101-111.

Potter, C., S. Klooster, A. Huete, and V. Genovese. 2007. Terrestrial carbon sinks for the United States predicted from MODIS satellite data and ecosystem modeling. Earth Interactions 11:1-21.

Potter, C. S., J. T. Randerson, C. B. Field, et al. 1993. Terrestrial ecosystem productiona process model-based on global satellite and surface data. Global Biogeochemical Cycles 7:811-841.

Prince, S. D., S. J., Goetz, and S. N. Goward. 1995. Monitoring primary production from Earth observing satellites. Water, Air and Soil Pollution 82:509-522.

Ruimy, A., B. Saugier, and G. Dedieu. 1994. Methodology for the estimation of terrestrial net primary production from remotely sensed data. Journal of Geophysical Research 99:5263-5283.

Running, S. W., D. D. Baldocchi, D. P. Turner, S. T. Gower, P. S. Bakwin, and K. A. Hibbard. 1999. A global terrestrial monitoring network integrating tower fluxes, flask sampling, ecosystem modeling and EOS satellite data. Remote Sensing of Environment 70:108-127.

Running, S. W., and R. R. Nemani. 1988. Relating seasonal patterns of the AVHRR vegetation index to simulated photosynthesis and transpiration of forests in different climates. Remote Sensing of Environment 24:347-367.

Running, S. W., R. R. Nemani, F. A. Heinsch, M. S. Zhao, M. Reeves, and H. Hashimoto. 2004. A continuous satellite-derived measure of global terrestrial primary production. BioScience 54:547-560. 
Running, S. W., L. Queen, and M. Thornton. 2000. The Earth observing system and forest management. Journal of Forestry 98:29-31.

Russell, G., P. G. Jarvis, and J. L. Monteith. 1989. Absorption of radiation by canopies and stand growth. In Plant canopies: Their growth, form and function, eds. G. Russell, B. Marshall, and P. G. Jarvis, 21-39. Cambridge, UK: Cambridge University Press.

Sakai, T. 2005. Microsite variation in light availability and photosynthesis in a cooltemperate deciduous broadleaf forest in central Japan. Ecological Research 20:537-545.

Salazar, M. R., B. Chaves, J. W. Jones, and A. Cooman. 2006. A simple potential production model of Cape gooseberry (Physalis peruviana L.). Acta Hortic 718:105-112.

Schwalm, C. R., T. A. Black, B. D. Amiro, et al. 2006. Photosynthetic light use efficiency of three biomes across an east-west continental-scale transect in Canada. Agricultural and Forest Meteorology 140:269-286.

Seaquist, J., L. Olsson, and J. Ardö. 2003. A remote sensing-based primary production model for grassland biomes. Ecological Modelling 169:131-155.

Seaquist, J. W., L. Olsson, J. Ardo, and L. Eklundh. 2006. Broad-scale increase in NPP quantified for the African Sahel, 1982-1999. International Journal of Remote Sensing 27:5115-5122.

Sims, D., and J. Gamon. 2002. Relationships between leaf pigment content and spectral reflectance across a wide range of species, leaf structures and developmental stages. Remote Sensing of Environment 81:337-354.

Sims, D., H. Luo, S. Hastings, W. Oechel, A. Rahman, and J. Gamon. 2006. Parallel adjustments in vegetation greenness and ecosystem $\mathrm{CO}_{2}$ exchange in response to drought in a southern California chaparral ecosystem. Remote Sensing of Environment 103:289-303.

Sims, D. A., A. F. Rahman, V. D. Cordova, et al. 2005. Midday values of gross $\mathrm{CO}_{2}$ flux and light use efficiency during satellite overpasses can be used to directly estimate eight-day mean flux. Agricultural and Forest Meteorology 131:1-12.

Still, C. J., J. Randerson, and I. Fung. 2004. Large-scale plant light-use efficiency inferred from the seasonal cycle of atmospheric $\mathrm{CO}_{2}$. Global Change Biology 10:1240-1252.

Storkey, J. 2006. A functional group approach to the management of UK arable weeds to support biological diversity. Weed Research 46:513-522.

Tracol, Y., E. Mougin, P. Hiernaux, and L. Jarlan. 2006. Testing a Sahelian grassland functioning model against herbage mass measurements. Ecological Modelling 193:437-446.

Tsubo, M., S. Walker, and H. O. Ogindo. 2005. A simulation model of cereal-legume intercropping systems for semi-arid regions I. Model development. Field Crops Research 93:10-22.

Tucker, C. J., I. Y. Fung, C. D. Keeling, and R. H. Gammon. 1986. Relationship between atmospheric $\mathrm{CO}_{2}$ variations and a satellite-derived vegetation index. Nature 319:195-199.

Tucker, C. J., W. H. Jones, W. A. Kley, and G. J. Sundstrom. A 3-band hand-held radiometer for field use. Science 211:281-283.

Tucker, C. J., C. O. Justice, and S. D. Prince. 1986. Monitoring the grasslands of the Sahel 1984-1985. International Journal of Remote Sensing 7:1571-1581. 
Tucker, C. J., and P. J. Sellers. 1986. Satellite remote-sensing of primary production. International Journal of Remote Sensing 7:1395-1416.

Turner, D. P., W. D. Ritts, W. B. Cohen, et al. 2003. Scaling gross primary production (GPP) over boreal and deciduous forest landscapes in support of MODIS GPP product validation. Remote Sensing of Environment 88:256-270.

Turner, D. P., W. D. Ritts, W. B. Cohen, T. K. Maeirsperger, S. T. Gower, and A. Kirschbaum. 2005. Site-level evaluation of satellite-based global terrestrial gross primary production and net primary production monitoring. Global Change Biology 11:666-684.

Turner, D. P., W. D. Ritts, W. B. Cohen, et al. 2006. Evaluation of MODIS NPP and GPP products across multiple biomes. Remote Sensing of Environment 102:282-292.

Turner, D. P., S. Urbanski, D. Bremer, et al. 2003. Cross-biome comparison of daily light use efficiency for gross primary production. Global Change Biology 9:383-395.

Ueyama, M., Y. Harazono, E. Ohtaki, and A. Miyata. 2006. Controlling factors on the inter-annual $\mathrm{CO}_{2}$ budget at a sub-arctic black spruce forest in interior Alaska. Tellus B 58:491-450.

Veroustraete, F., H. Sabbe, and H. Eerens. 2002. Estimation of carbon mass fluxes over Europe using the C-Fix model and Euroflux data. Remote Sensing of Environment 83:376-399.

Walcroft, A. S., K. J. Brown, W. S. F. Schuster, et al. 2005. Radiative transfer and carbon assimilation in relation to canopy architecture, foliage area distribution and clumping in a mature temperate rainforest canopy in New Zealand. Agricultural and Forest Meteorology 135:326-339.

Xiao, X. M. 2006. Light absorption by leaf chlorophyll and maximum light use efficiency. IEEE Transactions on Geoscience and Remote Sensing 44:1933-1935.

Xiao, X. M., Q. Y. Zhang, B. Braswell, et al. 2004. Modeling gross primary production of temperate deciduous broadleaf forest using satellite images and climate data. Remote Sensing of Environment 91:256-270.

Zhang, Q. Y., X. M. Xiao, B. Braswell, E. Linder, F. Baret, and B. Moore. 2005. Estimating light absorption by chlorophyll, leaf and canopy in a deciduous broadleaf forest using MODIS data and a radiative transfer model. Remote Sensing of Environment 99:357-371.

Zhao, M., F. A. Heinsch, R. R. Nemani, and S. W. Running. 2005. Improvements of the MODIS terrestrial gross and net primary production global data set. Remote Sensing of Environment 95:164-175.

\section{References}

Andrade, F. H., S. A. Uhart, and A. Cirilo. 1993. Temperature affects radiation use efficiency in maize. Field Crops Research 32:17-25.

Archibold, O. W. 1995. Ecology of world vegetation. London: Chapman \& Hall.

Asrar, G., M. Fuchs, E. T. Kanemasu, and J. L. Hatfield. 1984. Estimating absorbed photosynthetic radiation and leaf area index from spectral reflectance in wheat. Agronomy Iournal 76:300-306. 
Choudhury, B. J. 1987. Relationships between vegetation indices, radiation absorption, and net photosynthesis evaluated by a sensitivity analysis. Remote Sensing of Environment 22:209-233.

Cook, B. D., P. V. Bolstad, J. G. Martin, et al. 2008. Using light-use and production efficiency models to predict photosynthesis and net carbon exchange during forest canopy disturbance. Ecosustems 11:26-44.

Drolet, G. G., E. M. Middleton, K. F. Huemmrich, F. G. Hall, and H. A. Margolis. 2008. Regional mapping of gross light-use efficiency using MODIS spectral indices. Remote Sensing of Environment 112:3064-3078.

Fensholt, R., I. Sandholt, M. S. Rasmussen, S. Stisen, and A. Diouf. 2006. Evaluation of satellite based primary production modelling in the semi-arid Sahel. $\underline{\text { Remote }}$ Sensing of Environment 105:173-188.

Field, C. B., R. B. Jackson, and H. A. Mooney. 1995. Stomatal responses to increased $\mathrm{CO}_{2}$-Implications from the plant to the global scale. Plant Cell and Environment 18:1214-1225.

Filella, I., J. Peñuelas, L. Llorens, and M. Estiarte. 2004. Reflectance assessment of seasonal and annual changes in biomass and $\mathrm{CO}_{2}$ uptake of a Mediterranean shrubland submitted to experimental warming and drought. Remote Sensing of Environment 90:308-318.

Fisher, B., R. K. Turner, and P. Morling. 2009. Defining and classifying ecosystem services for decision making. Ecological Economics 3:643-653.

Gamon, J. A., C. B. Field, M. L. Goulden, et al.1995. Relationships between NDVI, canopy structure, and photosynthesis in 3 Californian vegetation types. Ecological Applications 5:28-41.

Garbulsky, M. F., J. Peñuelas, D. Papale, et al. 2010. Patterns and controls of the variability of radiation use efficiency and primary productivity across terrestrial ecosystems. Global Ecolooy and Biogeooraphy 19:253-267.

Gower, S. T., C. J. Kucharik, and J. M. Norman. 1999. Direct and indirect estimation of leaf area index, $f(A P A R)$, and net primary production of terrestrial ecosystems. Remote Sensing of Environment 70:29-51.

Grace, J., C. Nichol, M. Disney, L. T. Quaife, and P. Bowyer. 2007. Can we measure terrestrial photosynthesis from space directly, using spectral reflectance and fluorescence? Global Change Biolooy 13:1484-1497.

Gu, L., D. Baldocchi, S. B. Verma, et al. 2002. Advantages of diffuse radiation for terrestrial ecosystem productivity. Journal of Geophysical Research: Atmospheres 107:2-23.

Hilker, T., N. C. Coops, M. A. Wulder, T. A. Black, and R. G. Guy. 2008. The use of remote sensing in light use efficiency based models of gross primary production: A review of current status and future requirements. Science of the Total Environment 404:411-423.

Ito, A., and T. Oikawa. 2007. Absorption of photosynthetically active radiation, drymatter production, and light-use efficiency of terrestrial vegetation: A global model simulation. Elsevier Oceanooraphy Series 73:335-359; 503-505.

Jenkins, J. P., A. D. Richardson, B. H. Braswell, S. V. Ollinger, D. Y. Hollinger, and M. L. Smith. 2007. Refining light-use efficiency calculations for a deciduous forest canopy using simultaneous tower-based carbon flux and radiometric measurements. Agricultural and Forest Meteorolooy 143:64-79.

Kiniry, J. R., J. A. Landivar, M. Witt, T. J. Gerik, J. Cavero, and L. J. Wade. 1998. Radiation-use efficiency response to vapor pressure deficit for maize and sorghum. Field Crops Research 56:265-270. 
Los, S. O., G. J. Collatz, P. J. Sellers, et al. 2000. A global 9-yr biophysical land surface dataset from NOAA AVHRR data. Iournal of Hydrometeorology 1:183-199.

MA (Millennium Ecosystem Assessment). 2005. Ecosystems and human well-being: The assessment series (four volumes and summary). Washington, DC: Island Press.

Maselli, F., M. Chiesi, M. Moriondo, L. Fibbi, M. Bindi, and S. W. Running. 2009. Modelling the forest carbon budget of a Mediterranean region through the integration of ground and satellite data. Ecological Modelling 220:330-342.

McNaughton, S. J., M. Oesterheld, D. A. Frank, and K. J. Williams. 1989. Ecosystemlevel patterns of primary productivity and herbivory in terrestrial habitats. Nature 341:142-144.

Monteith, J. L. 1972. Solar radiation and productivity in tropical ecosystems. Lournal of Applied Ecology 9:747-766.

Nouvellon, Y., D. L. Seen, S. Rambal, et al. 2000. Time course of radiation use efficiency in a shortgrass ecosystem: Consequences for remotely sensed estimation of primary production. Remote Sensing of Environment 71:43-55.

Paruelo, J. M., M. F. Garbulsky, J. P. Guerschman, and E. G. Jobbágy. 2004. Two decades of Normalized Difference Vegetation Index changes in South America: Identifying the imprint of global change. International Journal of Remote Sensing 25:2793-2806.

Pereira, J. S., J. A. Mateus, L. Aires, et al. 2007. Net ecosystem carbon exchange in three contrasting Mediterranean ecosystems-The effect of drought. Biogeosciences 4:791-802.

Piñeiro, G., M. Oesterheld, and J. M. Paruelo. 2006. Seasonal variation in aboveground production and radiation-use efficiency of temperate rangelands estimated through remote sensing. Ecosustems 9:357-373.

Potter, C. S. 1993. Terrestrial ecosystem production: A process model based on global satellite and surface data. Global Biogeochemical Cycles 7:811-841.

Ruimy, A., P. Jarvis, D. D. Baldocchi, and B. Saugier. 1995. $\mathrm{CO}_{2}$ fluxes over plant canopies and solar radiation: A review. Advances in Ecological Research 26:1-68.

Ruimy, A., L. Kergoat, A. Bondeau, et al. 1999. Comparing global NPP models of terrestrial net primary productivity (NPP): Analysis of differences in light absorption and light-use efficiency. Global Change Biolooy 5:56-64.

Sala, O. E., R. B. Jackson, H. A. Mooney, and R. W. Howarth. 2000. Methods in ecosystem science: Progress, tradeoffs, and limitations. In Methods in ecosystem science, eds. O. E. Sala, R. B. Jackson, H. A. Mooney, and R. W. Howarth, 1-3. New York: Springer-Verlag.

Scurlock, J. M. O., W. Cramer, R. J. Olson, W. J. Parton, and S. D. Prince. 1999. Terrestrial NPP: Toward a consistent data set for global model evaluation. Ecological Applications 9:913-919.

Sellers, P. J., J. A. Berry, G. J. Collatz, C. B. Field, and E. G. Hall. 1992. Canopy reflectance, photosynthesis, and transpiration. III. A reanalysis using improved leaf models and a new canopy integration scheme. Remote Sensing of Environment 42:187-216.

Sellers, P. J., C. J. Tucker, G. J. Collatz, et al. 1994. A global 1-degrees by 1 degrees NDVI data set for climate studies. The generation of global fields of terrestrial biophysical parameters from the NDVI. International Journal of Remote Sensing 15:3519-3545.

Still, C. J., J. T. Randerson, and I. Y. Fung. 2004. Large-scale plant light-use efficiency inferred from the seasonal cycle of atmospheric $\mathrm{CO}_{2}$. Global Change Biolooy 10:1240-1252. 
Tong, X. J., J. Li, and L. Wang. 2008. A review on radiation use efficiency of the cropland. Chinese Journal of Ecology 27:1021-1028.

Turner, D. P., S. T. Gower, W. B. Cohen, M. Gregory, and T. K. Maiersperger. 2002. Effects of spatial variability in light use efficiency on satellite-based NPP monitoring. Remote Sensing of Environment 80:397-405.

Turner, D. P., W. D. Ritts, W. B. Cohen, et al. 2005. Site-level evaluation of satellitebased global terrestrial gross primary production and net primary production monitoring. Global Change Biology 11:666-684.

Turner, D. P., S. Urbanski, D. Bremer, et al. 2003. A cross-biome comparison of daily light use efficiency for gross primary production. Global Change Biology 9:383-395.

Zhao, Y. M., S. K. Niu, J. B. Wang, H. T. Li, and G. C. Li. 2007. Light use efficiency of vegetation: A review. Chinese Journal of Ecology 26:1471-1477. 